\title{
Efficacy of Plants Extract in the Control of Cowpea Weevils (Collosobranchus maculatus) in Storage at Gombe and Makurdi, Nigeria
}

\author{
Esang, D. M., Madina, P. ${ }^{*}$ and Ahmed, J. \\ Department of Crop Production Joseph Sarwuan Tarka University (JOSTUM), Makurdi, Benue State. Nigeria. \\ *Corresponding Author E-mail: madinapaul26@yahoo.com
}

\begin{abstract}
Callosobruchus maculatus, a major storage insect pest of cowpea, lays its eggs on the pods or sometimes on the seeds both in the field and in storage. The larva perforates the seeds and completes its life cycle there. It can cause loss, if not controlled in time. The objective of this project was to examine the effect of plants extracts (Neem seed powder, Moringa seed powder and Pepper seed powder) on cowpea weevils as an alternative for preserving cowpea at storage at Gombe and Makurdi. The experimental design for the study was Completely Randomized Design with three replications. Data collected included; number of perforated seeds, number of mortality, number of eggs, number of adult weevils, germination percentage and weight of cowpea before and after the experiment at 4 weeks and 8 weeks. Significant difference $(P<0.05)$ was recorded on cowpea variety and plant extracts were Sampea 11 (white cowpea) recorded low in number of perforated seeds, number of mortality, number of eggs, number of adult weevils and weight of cowpea before and after the experiment at 4 and 8 weeks after infestation with germination percentage high where Sampea 12 (brown cowpea) records higher in all the parameters considered except in germination percentage where it recorded low. On plant extracts, pepper seed powder recorded the lowest in number of perforated seeds, number of mortality, number of eggs, number of adult weevils, and weight of cowpea before and after the experiment at 4 weeks and 8 weeks with germination percentage high, control on the other hand recorded the highest in all the parameter in consideration except in germination percentage. Hence, Sampea 11 (white cowpea) variety shows superiority over Sampea 12 (brown cowpea) variety in all the parameters under consideration. Pepper seed powder also shows superiority over the other plants extracts used; pepper powder with Sampea11 is therefore effective in the control of $C$. maculatus when compared with other plant extracts. On location, Gombe stored better using sampea11 (white cowpea) and pepper extracts. Therefore, the use of pepper seed powder by cowpea farmers for effective control of cowpea weevils in storage and should adopt Sampea 11 (white cowpea) variety since it has resistance to cowpea weevils during storage.
\end{abstract}

Keywords: Plants extracts, weevils and storage

\section{INTRODUCTION}

Cowpea (Vigna unguiculata L. Walp) is one of the most important grain-legume in the farming systems of Nigeria and West Africa at large (Singh et al., 2002). It accounts for about $60 \%$ of the protein intake in Nigeria (Oparaeke et al., 1998). Cowpea provides feed, forage, hay, and silage for livestock, and green manure and cover crop which maintain the productivity of soils (Alemu et al., 2016). In the agricultural system, it compensates for the loss of nitrogen absorbed by cereals, thus, it has a positive impact on soil properties. This is due to its unique capacity to fix atmospheric nitrogen and performs well even in poor soils (Rosenblueth et al., 2018). 
The crop has also weeds suppressing ability. Being a drought-tolerant and warm-weather crop, it is a promising food and forage species in a typical tropical lowland climate (Alemu et al., 2016; Belay et al., 2017; Bilatu et al., 2012). All the parts of cowpea used for food (fresh leaves, immature pods and the grains) are nutritious, providing protein, carbohydrate, vitamins and minerals (Tony et al., 2014). The grain contains $22-23 \%$ protein and food quality of thiamine (vitamin $B_{1}$ ), riboflavin (vitamin $B_{2}$ ) and niacin (vitamin $B_{3}$ ), and richer than cereals in iron and calcium content. Cowpea leaves are a significant source of carotene and ascorbic acid (vitamin C) (Tony et al., 2014). Cowpeas seed grain used as food, supplement very well the protein deficiency of the predominantly carbohydrate, cereal, root and plantain diet of African communities (Tony et al., 2014). In industrialized countries as the United States and Australia, varieties of cowpea types are cooked, canned or frozen to make the ready to serve (Quinn, 1999).

Although there have been successes of cowpea production in the country and major producing regional levels, little is known about its production, productivity, distribution, importance, and utilization (FAO, 2004). The yields of cowpea have generally remained below the potential of the crop and consistently remained below the world averages. The lack of information and sustained production is indicative of the fact that the production of cowpea is dominated by small-scale farming. The productivity of cowpea in the country are hindered by the lack of access to modern technologies such as improved varieties and the accompanying crop and pest management practices, inputs such as fertilizers (both mineral and bio fertilizers), seeds of improved varieties, and poor storage and market handling. Nigeria is the largest producer and consumer of cowpea in the world with a national average yield of about 669 pounds per acre, or 750 kilograms per hectare (Nkechi, 2017). There are some dual-purpose (grain and fodder) varieties for dry Savanna areas. Savanna zone for medium/late maturing varieties (70-86 days), plant from late July to mid-August. For early maturing varieties (55-69 days), commencing planting from mid-August to the end of August (IITA, 2017).

Biotic factors are responsible for these losses in the field, most importantly insect pests' infestations at all stages of the plant growth in the field and also in the store (Oparaeke et al., 2004). Callosobruchus maculatusis a major primary pest of stored seeds of cowpea in Nigeria (Ofuya, 2001). Infestation usually starts from the field and continues in the store where the seeds are severely damaged, leading to reduced weight, low viability and poor marketability (Ofuya, 1986), these losses constitute a major threat to food security and availability. The common control method of storage pests is with synthetic insecticides such as pirimiphos-methyl, fenithrithion, methyl bromide and phosphine fumigant (Cardona and Karel, 1990; Monford, 2006). Although these chemicals appear to be effective, their use is being discouraged due to associated human health and environmental problems such as pest resistance to insecticide, environmental pollution, high cost of purchase, non-availability as well as hazards to farmers (Talukder and Howse, 1995). These drawbacks have necessitated the need for sustainable alternatives that are easily bio degradable, environmentally friendly and safe to both producers and consumers (Akob and Ewete, 2007). The challenge of finding a good alternative to replace these conventional insecticides has led to bioprospecting for plants with natural insecticidal potency. Some plants where their leaves, stems, roots have been used include Azadirachta indica, Piper guineense, Allium cepa, Anethum graveolens, Senna species, Annona senegalensis (Ewete et al., 1996, Ofuya, 2001) among others. The pulverized leaves of Neem, Moringa and Pepper have been found to be effective against storage pest like Tribolium castaneum (Herbst.) (Anita et al., 2012). The objective of this study is as follows: to determine which among the plants extract is effective for the control of cowpea beetle (C. maculatus) and to determine which of the variety is resistant to weevil infestation.

\section{MATERIALS AND METHODS}

The field experiment was carried out in the Crop Production Laboratory, Collage of Agronomy in the Joseph Sarwuan Tarka University Makurdi, Benue State and Government Science Secondary School Billiri Laboratory, Gombe Nigeria under room temperature of $28-30^{\circ} \mathrm{C}$. Makurdi is situated on longitude $7^{\circ} 47^{\prime} 36^{\prime \prime} \mathrm{N}$ and latitude 8037'10". Billiri Gombe is situated at (950'N and $\left.11^{\circ} 09^{\prime} \mathrm{E}\right)$. The study area is warm tropical climate characterized by wet and dry seasons. A Complete Randomized Design (CRD) with three replications was used for the experiment. The experiments were setup using non-infested cowpea seeds. The treatment consisted of Neem seed powder, Moringa seed powder and Pepper seeds powder. The treatment before the experiment was kept in an oven for 24 hours at $50^{\circ} \mathrm{C}$. The amount of seeds powder used for each of the treatments was $5 \mathrm{~g}$ which was added into each container with $50 \mathrm{~g}$ of cowpea seeds and 10 cowpea weevils (C. Maculatus). Data on germination percentage was calculated using ${ }^{\circ}$ the following equation:

Germination percentage $=\frac{\text { number of seeds with holes }}{\text { number of whole seeds }} \times 100$ 
Also, percentage of cowpea seeds with holes was calculated using the equation

Percentage of Cowpea Seeds with Holes $=\frac{\text { number of cowpea seeds with holes }}{\text { number of the whole copea seeds }} \times 100$

Weevil's mortality was estimated by counting the number of dead and alive adult weevil in each experimental treatment during the storage period of 4 and 8 weeks. An insect was considered dead when it showed no sign of movement when lightly touched or when it was found lying on its back without kicking (Adu-Acheampong, 1997). Mortality of Weevils (C. maculatus) was calculated using the equation below:

Mortality of Weevils (C. maculatus) $=\frac{\text { number of dead weevils }}{\text { total number of alive weevils }} \times 100$

Data was analyzed statistically using Analysis of Variance (ANOVA) GENSTAT Discovery Edition 17. Means were separated using Least Significant Difference (LSD), $(P<0.005)$ at $95 \%$ level of probability.

\section{RESULTS AND DISCUSSION}

Table 1 is the efficacy of plants extracts and varieties in the control of cowpea weevils at 4 weeks of infestation in Makurdi, Benue State. Nigeria on number of perforation, number mortality, number of eggs and number adults at four (4) weeks of infestation. The result indicates that cowpea variety is significantly difference $(P<0.05)$ in number of mortality and number of weevil adults where Sampea 11 has the lowest number of perforation, number mortality, number of eggs and number adults when compared with Sampea 12, this could be associated with genetic make-up of the seeds, seed coat and other phytochemical component as reported by Ewete et al. (1996) who stated that, phytochemical component and genetic make-up affect the seed vulnerability to insect pest attack both in field and in storage.

The result in (Table 1) also indicates that plants extract is significantly $(\mathrm{P}<0.05)$ difference with pepper powder recorded the lower number of perforation, number of eggs, lower number of adult and higher number of mortality, when compared to other treatments (Moringa powder, Neem powder and the control) this can be an indication that pepper power as a positive effect in the control of cowpea weevil while in storage, this accretion is supported by the finding of Kaita et al. (2010) who agrees with the report of this work stating that pepper power has a component that inhibit weevils activities and proliferation in stored cowpea. This work is supported by the report of Tony et al. (2014). Who started that the effective control of the cowpea weevil was observed from the combination of neem and pepper suggests that the control is predominantly due to the effect of pepper rather than that of neem. This is because neem on its own, gave rather poor control while pepper gave good control of the storage pest. However, other studies using neem oil and kernel powder have proved effective as storage protectants against cowpea weevil, bean bruchid, beetles and grain borers. Thus different plant parts can give different effects on the storage pest. Neem leaves have been found to contain much less of the major active ingredient, than seed kernels and therefore, not commonly used.

Table 1 equally reported that location has significant difference $(\mathrm{P}<0.05)$ in number of perforation, number mortality, number of eggs and number adults where Gombe recorded the least number of perforation, number of eggs, number adults and high in adult mortality when compared with Makurdi, this could be as a result of ambient temperature which affected the proliferation of the weevil causing much damage in Makurdi than Gombe, Ito and Ighere (2017) lend supported to this finding starting that temperature, relative humidity and also plant extracts concentration affects cowpea storage in relation to weevils damage so also Monford et al. (2006).

Table 2 shows the efficacy of plants extracts and varieties in the control of cowpea weevils (C. maculatus) at 8 weeks of infestation in Makurdi, Benue State. Nigeria. The result indicates that cowpea varieties is significantly difference $(P<0.05)$ where Sampea 11 recorded lower in number of perforation, number of eggs and number of adult, while Sampea 12 recorded lower number of mortality compared with the Sampea 11, this could be associated with genetic make-up of the seeds, seed coat as reported by Boukar et al (2018) who stated that seeds coat, taste, chemical composition and genetic make-up affect the seed vulnerability to insect pest attack in storage.

The result in (Table 2) also indicates significantly $(P<0.05)$ difference in plants extract on number of perforation, number of eggs and number of adult and number of mortality where pepper powder has the least number of perforation, number of eggs and number of adult and high in number of mortality when compared with other plant extract used (Moringa powder, Neem powder and the Control) this can be an indication that pepper power as a positive effect in the control of weevil of cowpea while in storage, this accretion is supported by the finding of Ajayi and Adedira (2003) who collaborated with the finding in this work stating that when plant extracts like pepper powder stays for a long time during storage it brings out other chemical component that affect weevils activities thereby controlling store cowpea he added that black pepper is a spice used in food 
Table 1: Efficacy of plants extracts and varieties in the control of cowpea weevils at 4 weeks of infestation in Makurdi, Benue State. Nigeria.

\begin{tabular}{lllll}
\hline Varieties (V) & No. of perforated & No. of mortality & No of eggs & No. of Adult \\
\hline Sampea 11 & 5.21 & 8.61 & 2.21 & 4.64 \\
Sampea 12 & 7.92 & 5.02 & 3.21 & 5.01 \\
F-LSD (0.05) & 2.00 & 1.67 & 1.01 & 1.02 \\
\hline Plants extract (P) & & & & \\
\hline Neem & 5.78 & 6.21 & 4.31 & 5.31 \\
Moringa & 7.21 & 8.53 & 5.62 & 6.81 \\
Pepper & 4.21 & 3.21 & 2.11 & 3.11 \\
Control & 9.25 & 11.28 & 8.21 & 7.61 \\
F-LSD (0.05) & 1.04 & 2.01 & 1.04 & 1.06 \\
\hline Location & & & & \\
\hline Gombe & 4.23 & 6.23 & 2.78 & 4.12 \\
Makurdi & 5.23 & 5.11 & 4.01 & 5.88 \\
F-LSD (0.05) & 1.00 & 0.89 & 1.64 & 1.01 \\
\hline Interaction & & & & \\
\hline VXP & NS & * & NS & *
\end{tabular}

$\mathrm{V}=$ Variety, $\mathrm{P}=$ Plants extracts, F-LSD= Fisher's least significant difference at $5 \%$ level of probability, NS= Not significant.

Table 2: Efficacy of plants extracts and varieties in the control of cowpea weevils at 8 weeks of infestation in Makurdi, Benue State. Nigeria.

\begin{tabular}{|c|c|c|c|c|}
\hline Varieties (V) & No. of perforated & No. of mortality & No of eggs & No. of Adult \\
\hline Sampea 11 & 6.31 & 16.26 & 6.81 & 4.64 \\
\hline Sampea 12 & 8.22 & 11.62 & 8.21 & 5.01 \\
\hline F-LSD (0.05) & 2.10 & 3.17 & 1.01 & 1.02 \\
\hline \multicolumn{5}{|c|}{ Plants extract $(\mathrm{P})$} \\
\hline Neem & 7.18 & 12.21 & 9.31 & 9.81 \\
\hline Moringa & 8.23 & 10.31 & 19.12 & 10.31 \\
\hline Pepper & 4.51 & 18.42 & 3.11 & 4.21 \\
\hline Control & 10.65 & 6.28 & 12.02 & 14.31 \\
\hline F-LSD (0.05) & 2.04 & 2.01 & 4.04 & 1.04 \\
\hline \multicolumn{5}{|l|}{ Location } \\
\hline Gombe & 5.12 & 9.12 & 3.69 & 5.12 \\
\hline Makurdi & 6.98 & 6.12 & 5.99 & 7.51 \\
\hline F-LSD (0.05) & 1.00 & 2.12 & 0.12 & 1.57 \\
\hline \multicolumn{5}{|l|}{ Interaction } \\
\hline $\mathrm{VXP}$ & NS & * & NS & * \\
\hline
\end{tabular}

seasoning and therefore it does not pose a health hazard either to consumers or the environment. In areas where black pepper thrives well, it is advised that farmers grow the crop not only for commercial use and as spice but also as a good protectant of products against the cowpea weevil. Black pepper powder may as well be used for controlling the storage pest since they pose minimal risk to consumers and the environment. Adedire (2003) disagree with the finding in this work stating that plant extracts may affect the taste of the seeds in storage making it not accepted in the market. Although all plant extracts are significant at $(P<0.05)$ this revealed that all the tested plants extracts were not toxic and could be used as protectant against C. maculatus. The results of this study are in conformity to some degree with the report of some workers, like Opareke and Dike (2005), Adedire et al. (2011), Mukanga et al. (2010), lleke and Oni (2011), who observed that certain botanicals are effectively toxic against storage insect pests including $C$. maculatus. The resultant mortality rates of $C$. maculatus in this investigation could be attributed to the toxic effects of the chemicals in the tested plant species. Although all the plants showed promise as insecticides their toxicity against $C$. maculatus varied probably because of the different phytochemical contents. These findings are consistent with results of this study where black pepper 
Table 3: Efficacy of plants extracts and varieties in the control of cowpea weevils on weight of cowpea before, after, number of holes per sees and germination percentage in Makurdi, Benue State, Nigeria.

\begin{tabular}{|c|c|c|c|}
\hline Varieties (V) & Before (g) & After (g) & Germination (\%) \\
\hline Sampea 11 & 50.00 & 41.21 & 90.43 \\
\hline Sampea 12 & 50.00 & 32.34 & 85.76 \\
\hline F-LSD $(0.05)$ & - & 10.21 & 3.23 \\
\hline \multicolumn{4}{|c|}{ Plants extract $(\mathrm{P})$} \\
\hline Neem & 50.00 & 38.32 & 85.89 \\
\hline Moringa & 50.00 & 30.14 & 87.67 \\
\hline Pepper & 50.00 & 40.21 & 88.45 \\
\hline Control & 50.00 & 28.28 & 74.21 \\
\hline F-LSD $(0.05)$ & & 8.01 & 2.12 \\
\hline \multicolumn{4}{|l|}{ Location } \\
\hline Gombe & 50.00 & 41.32 & 95.23 \\
\hline Makurdi & 50.00 & 38.12 & 89.65 \\
\hline F-LSD (0.05) & - & 8.34 & 5.12 \\
\hline \multicolumn{4}{|l|}{ Interaction } \\
\hline $\mathrm{VXP}$ & NS & NS & * \\
\hline
\end{tabular}

Table 4: Interaction between varieties and plant extracts on the control of cowpea weevils in Makurdi, Benue state. Nigeria.

\begin{tabular}{lclll}
\hline Varieties (V) & Neem & Moringa & Pepper & Control \\
\hline Mortality & \multicolumn{5}{c}{} \\
Sampea 11 & 8.21 & 9.21 & 13.32 & 6.64 \\
Sampea 12 & 9.14 & 10.32 & 11.21 & 7.01 \\
F-LSD (0.05) & 1.00 & 1.07 & 2.01 & 1.00 \\
\hline Number of Adults & \multicolumn{5}{l}{} \\
\hline Sampea 11 & 5.32 & 6.21 & 3.82 & 6.94 \\
Sampea 12 & 6.92 & 8.02 & 4.92 & 7.21 \\
F-LSD (0.05) & 1.01 & 1.07 & 1.05 & 1.02 \\
\hline Germination percentage (\%) & \multicolumn{5}{c}{} \\
\hline Sampea 11 & 83.21 & 85.21 & 92.81 & 76.34 \\
Sampea 12 & 74.32 & 76.02 & 83.12 & 67.04 \\
F-LSD (0.05) & 1.01 & 1.01 & 1.01 & 1.02 \\
V= Variety, P= Plants extracts, F-LSD= Fisher's least & significant \\
difference at 5\% level of probability, NS= Not significant. &
\end{tabular}

powder reduced significantly the number of bruchids and consequently the number of damaged seeds.

On location there was a significant difference $(\mathrm{P}<0.05)$ in number of perforation, number mortality, number of eggs and number adults where Gombe recorded the least in all the parameters under consideration except in number of mortality when compared with Makurdi, this could be as a result of temperature which may have affected the proliferation of the weevil causing much damage in Makurdi than Gombe, Alghali (1992) lend supported to this finding starting that temperature, relative humidity and also plant extracts preparation affects cowpea storage in relation to weevils damage, he also added that it can also affect the phytochemical component of the seeds rendering its unaccepted when stored for long time.
Table 3 is the result showing efficacy of plants extracts and varieties in the control of cowpea weevils on weight of cowpea before, after experiment and germination percentage in Makurdi, Benue State. Nigeria. It shows significantly $(P<0.05)$ different with Sampea 11 having weightier seeds and higher germination percentage, this could be attributed to hard seed coat and ability to remain dormant as some seed exhibit which is uncommon with cowpea except if the condition is unfavorable, this finding is similar with the work of Dales (1996) who reported weightier seed in Sampea 11 variety and high germination percentage after treatment with chemical. Similarly, on plant extract, significantly $(P>0.05)$ different is recorded on weight of seed before and after experiment and germination percentage with pepper having weightier seeds and germination percentage 
numerically both statistically, this indicate that plants extract had no effect on cowpea seeds viability, Ilesanmi and Gungula (2013) affirm to the above accretion starting most eatable plant extract don't have effects on seeds viability. It is there possible to have viable seeds after treatment with plant extracts as reported by llesanmi and Gungula (2010).

The result from (Table 4) shows interaction between varieties and plant extracts on the control of cowpea weevils in Makurdi, Benue State, Nigeria. Significant difference $(P<0.05)$ between cowpea variety and plant extracts with Sampea 11 interacting perfectly with paper on adult mortality, number of adult and highest in germination percentage than Sampea 12 and other plant extracts, this could be link to the fact that white cowpea (sampea11) have hard seed coat when compared with brown cowpea (Sampea12) as reported by Manda et al., (2020) while Baukar et al (2018) also lend support to this finding starting that Sampea 12 have more phytochemical component than the white which make it vulnerable to attach by weevils and other insect pest. On the other hand, combination of control treatment with Sampea 11 recorded the lowest adult mortality, number of adult and lowest in germination percentage, this is not far from the fact that untreated cowpea is destroy fast by cowpea weevils leading to high lost in term of income reducing its market value, lost in taste and lost in viability as reported by FAO (1999).

\section{Conclusion}

The present investigation indicates that farmers can use local species of plants extras for protecting cowpea grains against cowpea weevil after harvest. The use of pepper seed powered with white cowpea (Sampea 11) has proven effective in the control of cowpea weevils in storage and it is therefore recommended to farmers in this two localities.

\section{REFERENCES}

Adedire, C. O. (2003). Use of nutmeg Myristica fragans (Houtt.) powder and oil for the control of cowpea storage bruchid, Callosobruchus maculatus (Fabricius). J Plt Dis Prot., 109(2): 193-199.

Adedire, C. O., Obembe, O. O., Akinkurolele, R. O. and Oduleye, O. (2011). Response of Callosobruchus maculatus (Coleoptera: Chysomelidae: Bruchidae) to extracts of cashew kernels. J Plt Dis Prot., 118(2): 75-79.

Ajayi, O. E. and Adedire, C. O. (2003). Insecticidal activity of an underutilized tropical plant; Hura crepitans (L.) seed oil on cowpea beetle, Callosobruchus maculatus (F) (Coleoptera: Bruchidae). Nig. J. Entomol., 20:74-81.

Akob, C. A. and F. K. Ewete. (2007). The efficacy of ashes of four locally used plant materials against Sitophilus zeamais (Coleoptera: Curculionidae) in Cameroon. International Journal of Tropical Insect Science, 27(1): $21-26$.

Alemu, U.R., Delobel, A. and P. Malonga, (2016). Insecticidal properties of six plant materials against Caryedon serratus (OI.) (Coleoptera: Bruchidae). J. Stored Prod. Res., 23: 173-176

Alghali, A. M. (1992). Insecticide application schedules to reduce grain yield losses caused by insect pests of cowpea in Nigeria. Insect Scence Applied, 13: 725 - 730.

Adu-Acheampong, H.A. (1997). Efficacy and persistence of certain plant powders against khapra beetle. Trogoderma granarium (Everts) Fayoum. J.Agric Res. Dev., 17:107-114

Anita, S., Sujatha, P. and Prabhudas, P. (2012). Efficacy of pulverized leaves of Annona squamosa (L.), Moringa oleifera (Lam.) and Eucalyptus globules (Labill.) against the stored grain pest, Tribolium castaneum (Herbst.). Recent Research in Science and Technology, 4(2):19-23.

Belay T.U., Elwell, H. and A. Maas, (2017). Natural pests and disease control. Natural Farming Network, Zimbabwe.

Bilatu G.H., Morse, S. and N. McNamara, (2012). Promoting sustainability efficacy and adoption of tobacco-based insecticides in Nigeria. J. Sustainable Agric., 24: 17-38.

Boukar, O., Belko, N., Chamarthi, S., Togola, A., Batieno, J. and Owusu, E. (2018). Cowpea (Vigna unguiculata): Genetics, genomics and breeding. Plant Breed. 2018. https:// doi. org/ 10. 1111/ pbr. 12589.

Cardona, P. and Karel, D.J., (1990). The Use of Plants and Minerals as Protectants of Stored Product Tropical Product Institute G138. PostHarvest Pest and Quality Section Natural Resource Institute, Cathan, UK., pp: 32.

Ewete, F. K., Arnasan, J. I. Larson J. and Philogene B. J. R. (1996) Biological activities of extracts from traditionally used Nigerian plants against European corn borer, Ostrinia nubilalis (H.). Entomol. Exp. Appl., 1996: 80: 531 - 537.

FAO. (1985). Handling and storage of food grains. Food and agricultural organisation of United Nations, Rome.

FAO. (1999) Botanical oils as grain protectants. In: The use of species and medicinal as bioactive protectants for grains. FAO Agricultural Services Bulletin, 1999: No.137. FAO, Vialledelle Terme di Caracalla, 00100 Rome, Italy.

FAO., (2004). Handling and Storage of Food Grains. Food and Agriculture Organization of the United Nations, Rome, Italy.

IITA (2010). Cowpea http://www.iita.org/cowpea. International Institute of Tropical Agriculture.

Ilesanmi J. O. and Gungula, D. T. (2013). Quality attributes of cowpea seeds stored with neem and Moringa seed oils. World Journal of Agricultural Science, $155-160$ http://dx.doi.org/10.5829/idosi.wjas.2013.9.2.1711

Ilesanmi, J. O., and Gungula, D. (2010). Preservation of Cowpea (Vigna unguiculata (L.) Walp) Grains against Cowpea Bruchids (Callosobruchus maculatus) Using Neem and Moringa Seed Oils. International Journal of Agronomy, 2010, 1-8. http://doi.org/10.1155/2010/235280

Ito, E, E. and Ighere, E. J. (2017). Basic Entomology and Pest Control, 1st Edition.

Keita, S. M., Vincent, C., Schmit, J. P., Arnason, J. T. and Bélanger, A. (2001). Efficacy of essential oil of Ocimum basilicum L. and $O$. gratissimum L. applied as an insecticidal fumigant and powder to control Callosobruchus maculatus (Fab.) (Coleoptera: Bruchidae). J Stored Prod Res., 37: 339-349.

Monford, K. G., (2006). Ipm the African Way African Farming and Food Processing. Hy-Line International, West Des Moines, lowa USA., pp: 17-20.

Monford, K. G., Adabie - Gomez, D. A., Agyir - Yawson, A., Owusu Biney, A. and Osae, M. (2006). Evaluation of four local plant species for insecticidal activity against Sitophilus zeamais Motsch. (Coleoptera: Curculionidae) and Callosobruchusmaculatus

(F.) (Coleoptera: Bruchidae). Ghana Journal of Agricultural Science, 39: 147-154.

Nkechi, P., (2017). Improvement in maize storage for the small holder farmer. Trop. Stored Prod. Inform., 50: 14-19.

Ofuya, T. I. (2001). Use of wood ash, dry chilli pepper fruits and onion scale leaves for reducing Callosobruchus maculatus ( $F$.) damage in 
cowpea seeds during storage. Journal of Agricultural Science, 107: $467-468$.

Ofuya, T.I., (1986). Oviposition deterrence and ovicidal properties of some plant powders against Callosobruchus maculatus in stored cowpea Vigna unguiculata seeds. J. Agric. Sci., 115: 343-345.

Oparaeke, A. M., Dike, M. C. and Amatobi, C. I. (2004). Field Evaluation of extracts of five Nigerian spices for control of post-flowering insect pests of cowpea, Vigna unguiculata (L.) Walp. Plant Protection Science, 41(1): $14-20$.

Oparaeke, A. M., Dike, M. C. and Onu, I. (1998). Evaluation of seed and leaf powders of neem (Azadirachta indica A. Juss) and Pirimiphos methyl for control of Callosobruchus maculatus (F.) in stored cowpea. Entomological Society of Nigeria Occasional Publication, 31: 237 242.

Quinn, R.L., (1999). New Opportunities in Vigna. In: Trends in New Crops and New Uses, Janick, J. and A. Whipkey (Eds.). ASHS Press, Alexandria, VA., pp: 424-428.

Rosenblueth L.O., Phillips, R.D and S.S. Dedeh., 2018. Developing nutritional and economic value added food products from cowpea. http://www.isp.msu.edu/crsp/Final. Rosenthal, G.A. and D.H. Janzeh, 1979. Herbivores Their Interaction with Secondary Plant Metabolites. Academic Press, New York.
Singh, B. B., Ehlers, J. D. Sharma, B. and Freire Filho, F. R. (2002). Recent progress in cowpea breeding. In: Fatokun, C. A., Tarawali, S. A., singh, B. B., Kormawa, P. M. and Tamo, M. (Eds.) Challenges and opportunity for enhancing sustainable cowpea production. Proceedings of the World Cowpea Conference III held at International Institute of Tropical Agriculture (IITA), Ibadan, Nigeria, IITA, Ibadan, Nigeria.

Talukder, F.R. and Howse Y.U., (1995). Neem a Tree for Solving Global Problems. National Academy Press, Washington, DC., USA.

Tony, N., James, O. and Nixon, T. (2014). Cowpea Production Handbook. College of Natural Resource and Environmental Study University of Juba. University Printing Press, Abraka, Delta State, Nigeria, p. 361. 